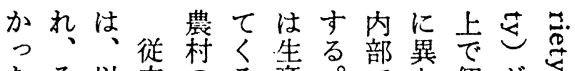

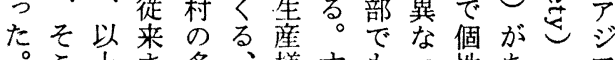

こ上多、様すもっ性古がア

そかので様と式な、たをるあの

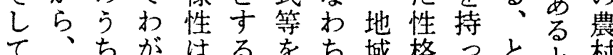

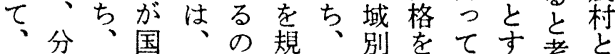

わ分々国きで唯言别持いる考と

がのくおおあと語差つる。势々

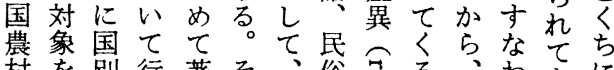

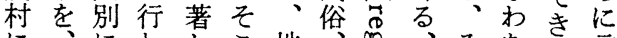

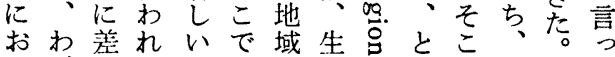

け怔異たも、相活导打各まて

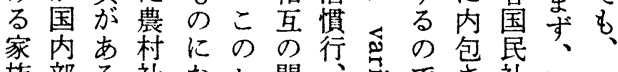

族部る社なと間究でさ社国一

や咅禽る。゙闰家市れ会別般

親農場学。ル異族しるて在行

族树を的まな形が。いそ差そ

のの前研でっ態見つるれ拱こ

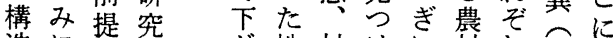

造にとの名性村けに符杂合は

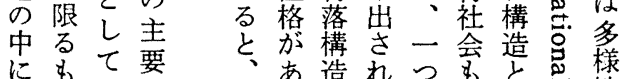

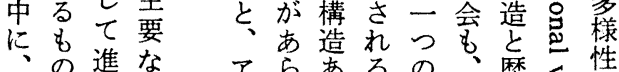

アらあるの、歴く性

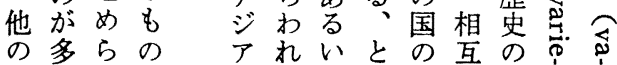

研觉に質涪いつっをて換も国

と究さし性了てかたて暗て言したの

こをてを農のかか、閫い寺からを

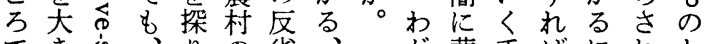

でき斿、か省、が葬手ばにれ

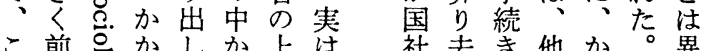

こ前。加し加㟧社去き他加。異

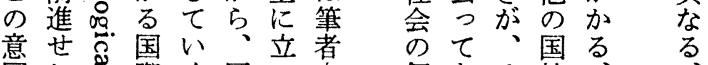

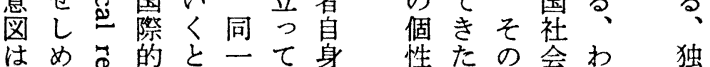

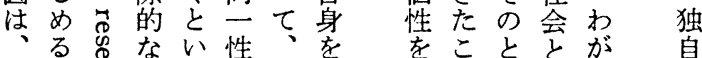

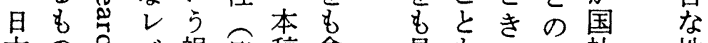

本の导 ベ視㑒稿含見高異社性

のと角邑でめ誤事時質会格

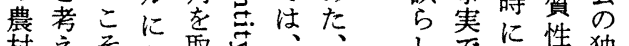

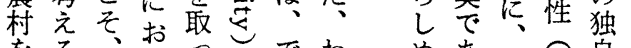

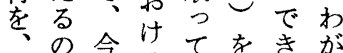

アで後るてをきが

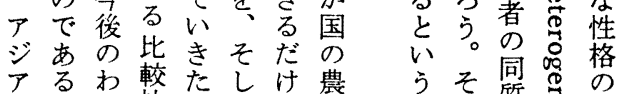

の。が社いて一柎

結し澌芭. 発

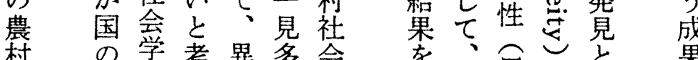

想農的考畋多拿

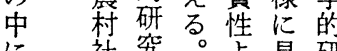

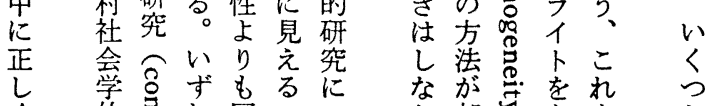

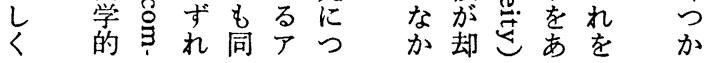




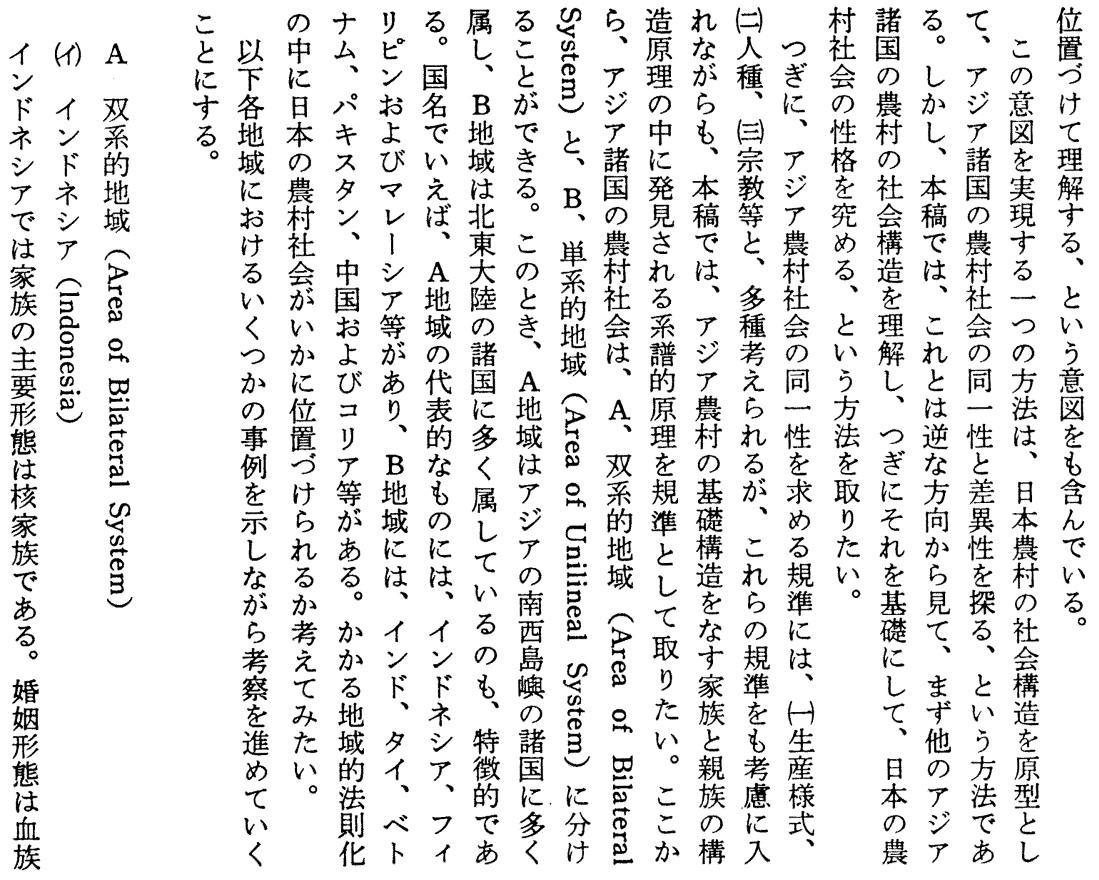

結婚しいを族の他あてこ。在い重し一にア体村結 婚㤎てとこ含と成のる農れパ九っ要生ず含のま采落婚 であ好ここんか人三が耕をラたたな活つま諸ずで外を

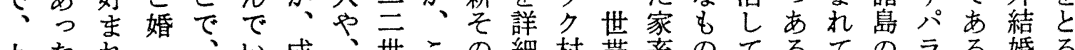
九たれ杂成、世この細村带畜のてるてのラる婚る 組。るきパる筫既带の他にのををでい。い中ク。がと

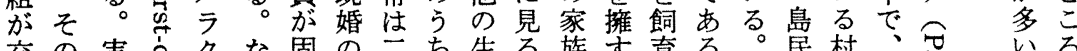

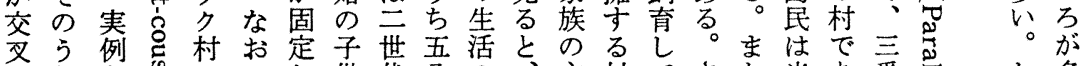

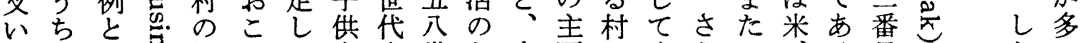
と二しる 婚のて夫家世た全要で生らケ、る目村的い

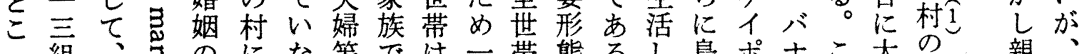

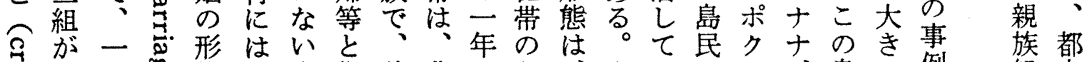

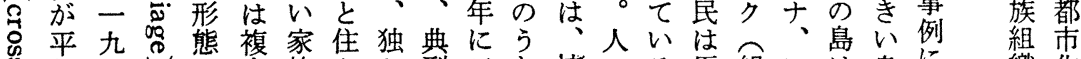
行五さ等族ん型三ち核口る馬絹いは島に織化

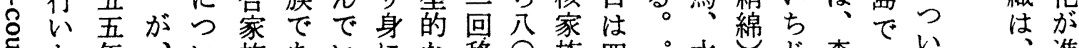

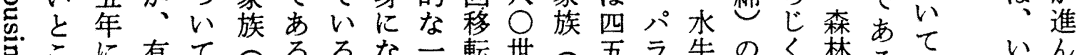

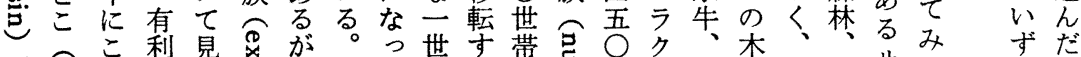

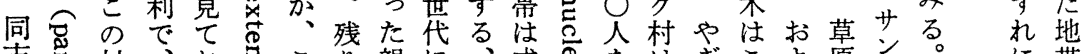

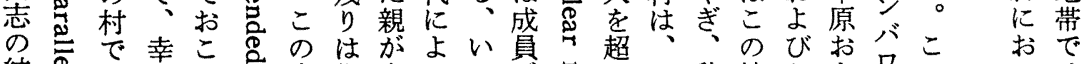

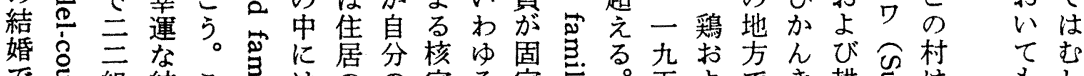

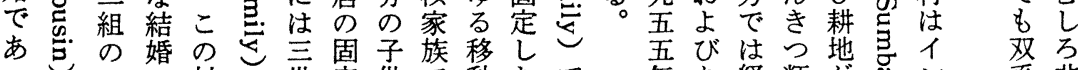
っいの村仙定供で動たで年あ経類が总ン系非

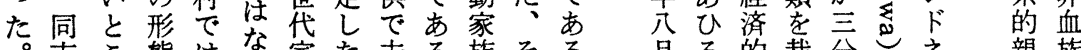
。志こ態はな家た末る族そる。る的栽分㜔族 なの結と㵀家婚。でし。現とに培の島シ 族の 


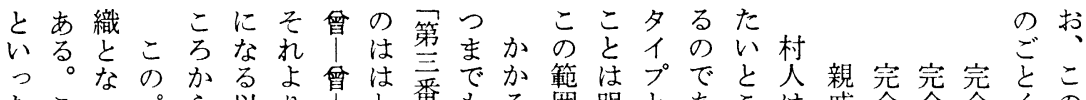

たこつパら以り「と番もる。用明とあこは戚全全全くの

方のて

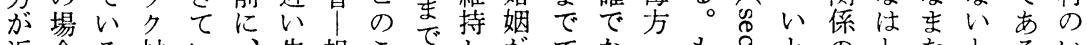

近合る村い先祖こで、しがでな

い。る゙と は

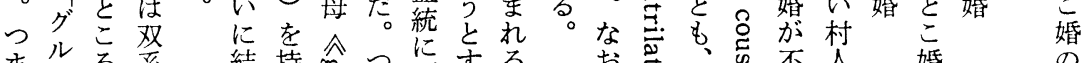

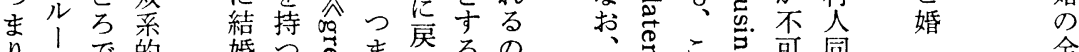

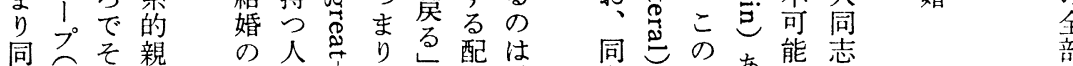

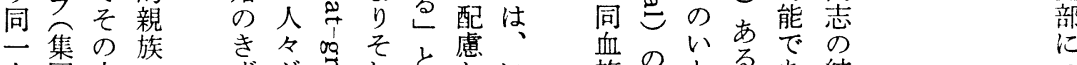

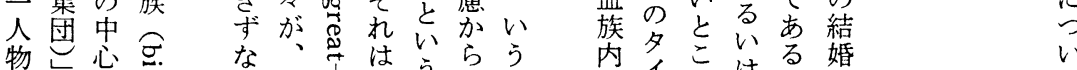

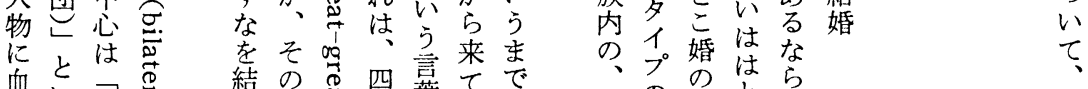

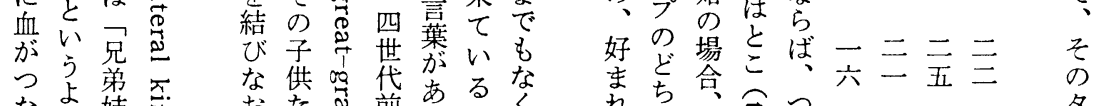

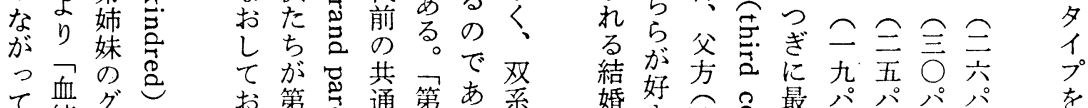

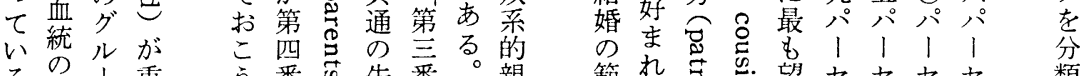

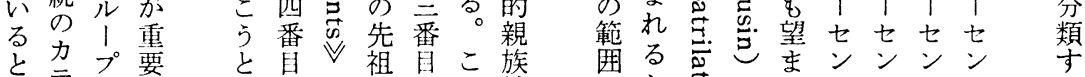

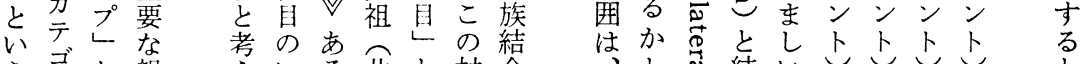

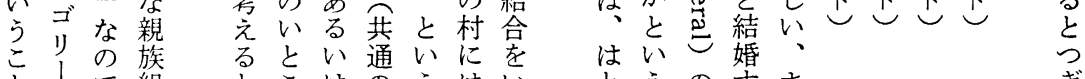

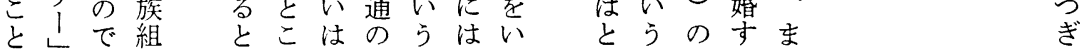

にとる。持性て 独が、

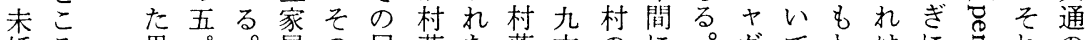

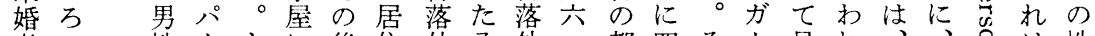

者で性1 女後住外八外二都四そ力見れ性

の老はセつ移形結九結年市二のルよるイこき焦格

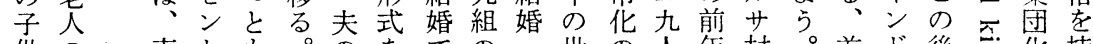

供の 妻卜\&

た場の以こと両兒あ結ミ带進とのは都ネ進芑へつ

ち合 数下のこ親るつつ婚市数展い二果 湆 シ 的可のて

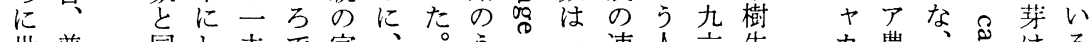

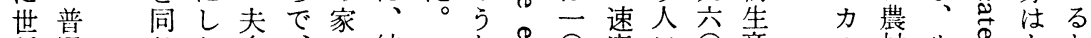

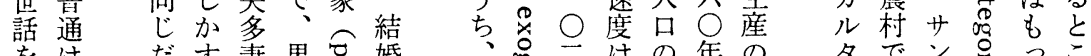

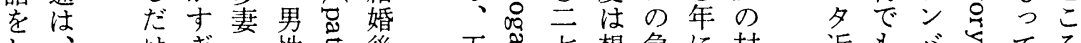

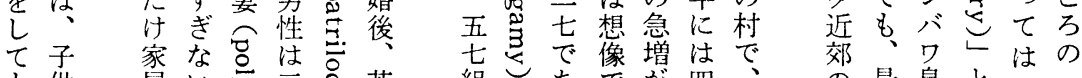

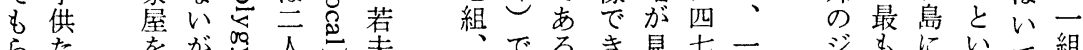

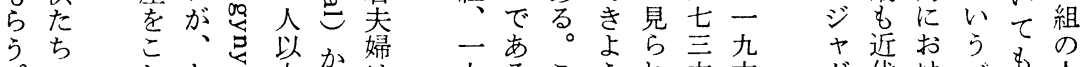

う。 こ

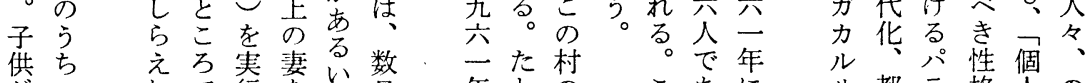

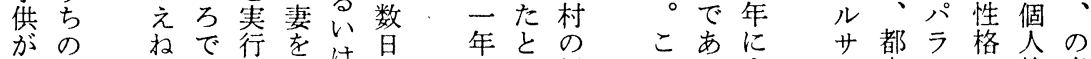

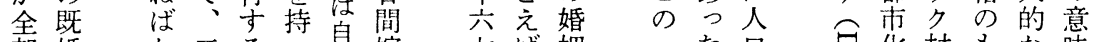

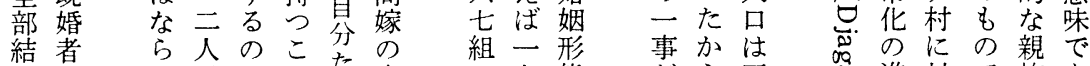

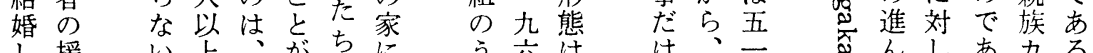

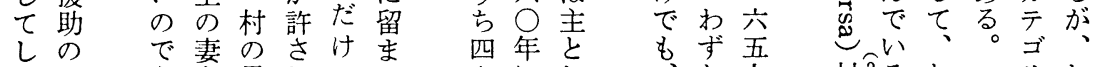

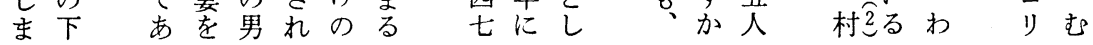


第 1 表 ジャガカルサ村における 世帯の大きさ

\begin{tabular}{|c|c|c|c|c|}
\hline \multirow{2}{*}{$\begin{array}{l}\text { 世帯の } \\
\text { 大きさ }\end{array}$} & \multicolumn{2}{|c|}{ 世 } & \multicolumn{2}{|c|}{ 数 } \\
\hline & $\begin{array}{l}\text { ジャガカ } \\
\text { ルサ村落 }\end{array}$ & $\begin{array}{l}\text { ババンカ } \\
\text { ン村落 }\end{array}$ & $\begin{array}{l}\text { クラパテ } \\
\text { イガ村落 }\end{array}$ & $\begin{array}{l}\text { カンダン } \\
\text { グ村落 }\end{array}$ \\
\hline 2 人 & 15 & 26 & 8 & 25 \\
\hline 3 & 61 & 46 & 32 & 40 \\
\hline 4 & 66 & 41 & 36 & 53 \\
\hline 5 & 54 & 51 & 17 & 60 \\
\hline 6 & 42 & 40 & 21 & 43 \\
\hline 7 & 50 & 16 & 15 & 36 \\
\hline 8 & 20 & 24 & 6 & 22 \\
\hline 9 & 9 & 10 & 8 & 14 \\
\hline 10 & 6 & 3 & 5 & 3 \\
\hline 11 & 2 & - & 1 & 1 \\
\hline 合 計 & 325 & 257 & 149 & 296 \\
\hline
\end{tabular}

小おも単くし人一う 村け自二こるてと人と、 落る然家のの彼一に 毎世そ屋村での緒残子 に带んをのあ妻にっ供 示員な持家るの生ての しのにち族。両活も一 た数大、形 親すら人 ををき単態とるうと で村もの主緒をう緒 あ内の世と好頼に るのに带し住むむ生 四なをて者。活 つらう核、がと寺 のなく家彼多こる 力いる族等いるか ン゚第向傾で の。で、 ン一がる地こ老る 表つ。をで人い 胥はよこ耕男たは 总ジ。核㤰にに車 吕ヤそ家るとは親 ガこ族必っ既の と力では要て婚家 呼ル世そがはのに ばサ带机生、娘子

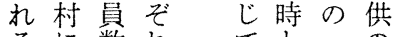
るに数れてと一の
在には、双 世るルず系 带村ソ、的リ 数落 七で島ピ系ン 三あにタでに

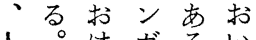
人。けガるい 口村るン 四民首 七水都尊 人田范 で経 三 あ営 ラ起 るに名 従 5 村

事乮洛

方到

て

いキて

る。見

。メ少

九 15

六ルこ 五のの

年位 村
の゙あるかせ、して常に訪依範れこ あいしぜかよ接る合囲はの フるはばいしりりといは叒核 1。まし、緊てこ、と系家 リたば近か密住乃救く的族 彼接かにんがけに親よ 自等しるなで多合明族り 分のた親るいいう確集大 た両世族傾る。。で団き ち親代間向場とこななな のののの合こういす 親 祖世メ相あ亦ろし場离族 父代ン互る多でた合怘集 母のバ扶。いジ親がき団 の 親 1 助

名戚 $\leftarrow$ \& 前のに さ人限唯 えのら 忘名れ同 前て世 世 た索䒫 导知 る。 るなか ら 傾かく文 向っし京 がたてし るり、人か
のヤ族あ屋は でガ関る宁ぺ 、係。次 そルのペ祭 のサ緊ルる゙リ 親村密ミ挙、事長 族でさリで密権村にと 関ははのあ志文長つし 係、各メる寻被選いて も父家ン。齿举て権 方庭バこと挙等、利 父のの|の呼権の家と 方親間は親呼を権族責 に戚の、族は持利を任 お距常集れ い通離に常団。

\section{いつすっ}

い権いの る利る核 な多家族 おつなの こてお中 いちで た。村名 簧具本中男 で的で は的夫 男村要が 性のな家 っを代を て 表 \& 
会 ガ 北

$$
\text { うのは近い的るる六で }
$$

あ族末日五限

の

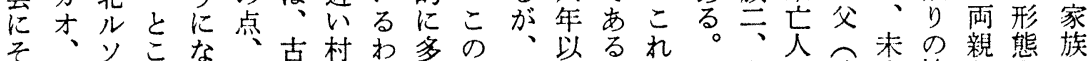

のボンろっ現老落けい村そ前。ら

典ンのでた在はので。のれにその

型卜マ、等はま地はむ婚以はの家

的クウフら変た域なろ姻後、点族

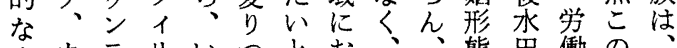

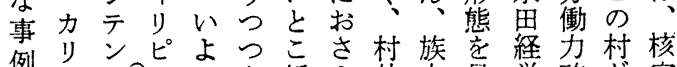

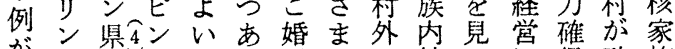

がガ界よる整っに結るに保砂族

見、令村変。好ても婚と転の糖每

らレすによとま分の、したたに

れハ点支てくれる散相村ためび单

るン㤩配いにたのし手内た複の二

。卜 的く若とでてはのめ合生家

こお㐌な゙者いあい、族核家産屋

のよす双ろ㤎うるる小内家族をに

う京系うマこ。村結族加主住

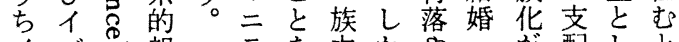

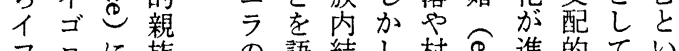

ブ㵀労語結し村@進的て心

ガ

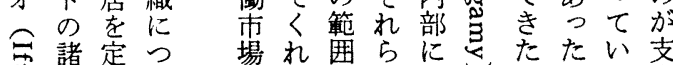

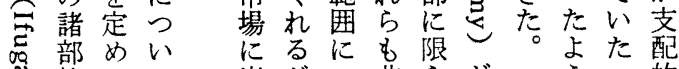

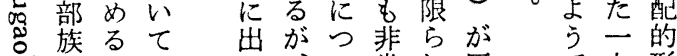

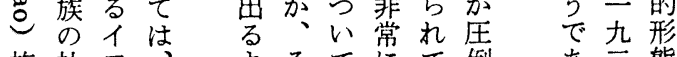

族社フ文をてにて倒 あ三態

女の独艺核と老の

性両り人家既兒ほ

亡親身に族婚ると

そとながのとん

白のつ四子つ

供未族母、のの核

た亡がと末二ご家

ち人一、未婚人うと族

家捨男のに核であ

族てや子な家ある。

三て \& 供

、顧めたたが。す

おみとち舟な

よら来にが居わ

びれ婚よ同しち

末なのる居て 元

婚く子家し い供挨て る 九

性ったがい家五

にたち四る族年

る供家末世五末 お

家た族亡代、け

族ち汃家一る

で家吾方族世代家

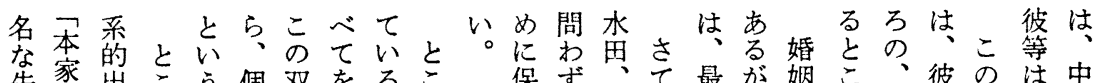

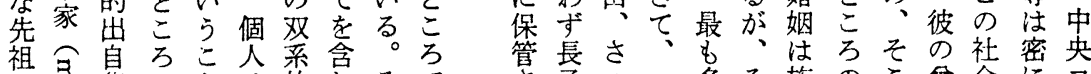

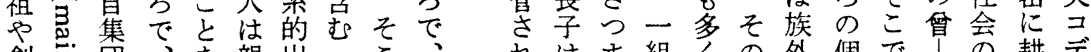
創引団、老親出二こ、机は組くの外個で!会耕デ

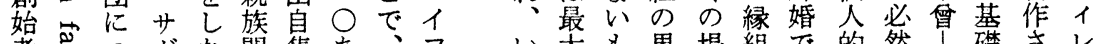

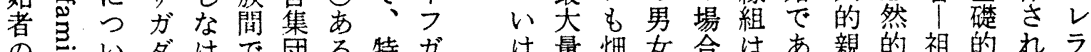
の寻い多けで団る特ガけ量畑女合はあ親的祖的れラ

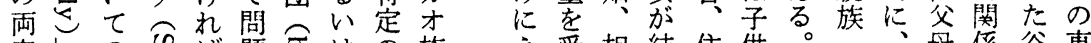

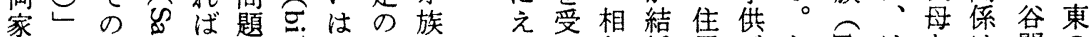

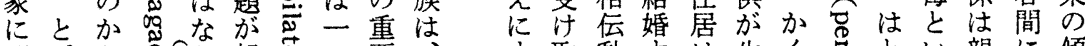

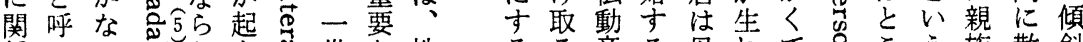

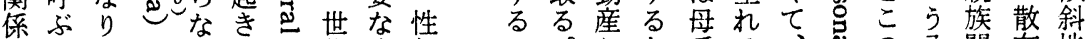

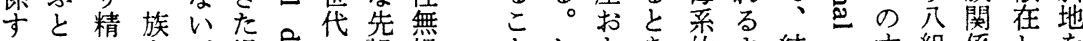

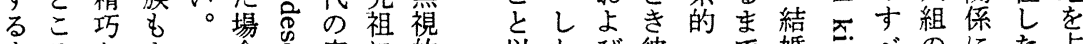
す万な合官家に的以かび彼で婚志べのにた占

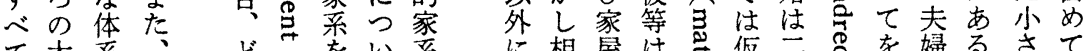
て大亲文をい采 のき范か方骂指て令

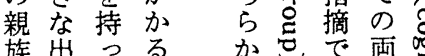

を自て性手系等

含集心無方はるにる

で団る。視忠複こたた。

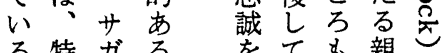

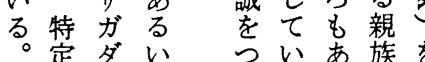

そ有が双方杂市す
に相屋は

は続な相

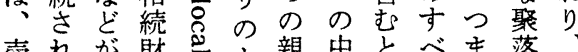

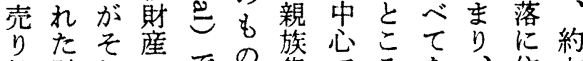

払財れ圱での篗でろを住七

う産で分あで団あま含おん方 こ应配る。のるでんので人 と文を考間。搪でおいを は親。受。の大势小の数 で族性けこ縁しるの省 きの別る。組てと個る 


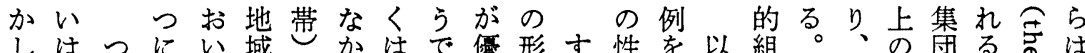

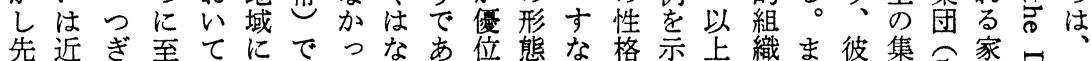

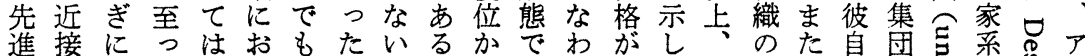

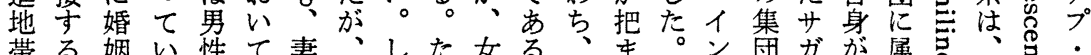

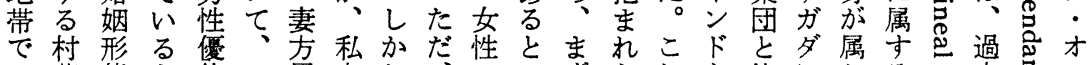

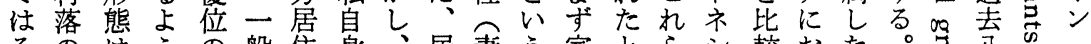
その注の般住身、居妻う家とら較おた。分お の地後で傾的婚、妻住要こ族おにアでいいすす乃号が

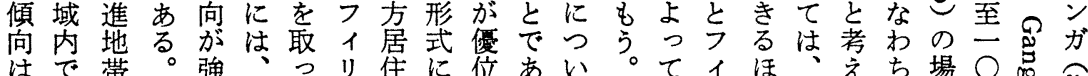

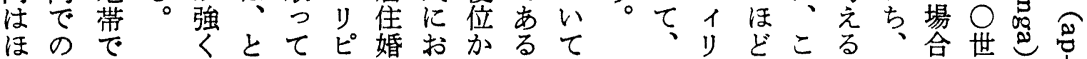

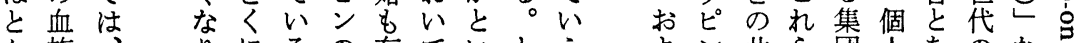
ん族、りにるの存ていとえ゙なン共ら団人ちのな ど結は、先例中在、うこば 薄婚と家進を部与二ころこ 机孞こ族的見ルる般とでの 多婚少なてソしには核地 逆以置長、いン、や、家域 にので と都る島本や原族の 非がのし市。の稿男則の一 血一村 て化た水で性的中般 族般落責のだ田事優にで的 の的内任進や地例位は、形 村で部息ん带とが決男態 落あの権だりへし見め性は 結る、利地双先七難っ核 婚。市带采進示れい方家 がる 持に的地さなよ族

そに同のあはが範ど』 双お団双る複っ焑之寻 采い体系い数ての呼哭 的て 的的はの、よばさ 地、な出諸加かうれす 域そ機自集入かでてな にれ能集団のるあいわ おぞを団を機親るるち けれ持灌会族個そガ る三さ家うで会集個そガ 族ずい所々持のはてガ とつるのがつ一単列の 親の。単でてつ采举親 族事采きお以的さ族

合

同 イ (1) B

家族ドイ単

をのン族俥

家ド的

く族气地

○寻域

て比导莡

る 的

の应

$\underset{\$}{\mathbb{B}}$

む势虽

特 家

徵 族

的

で多

c.

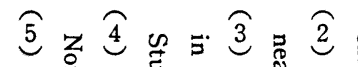

向先でるて

も通多

あ以 @

る

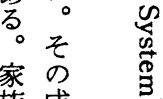

族 成

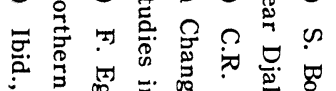

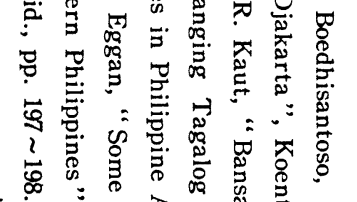

をさ豆出地ると親のの先な $\because \tau$ 带加こ双組外祖っ $\because$ きにと采織なをて ておいで的は持い 导いるううこ親なな引る。

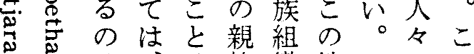
当は海織地の六 引・居原体の域親場 㔖わ住則系中で族合

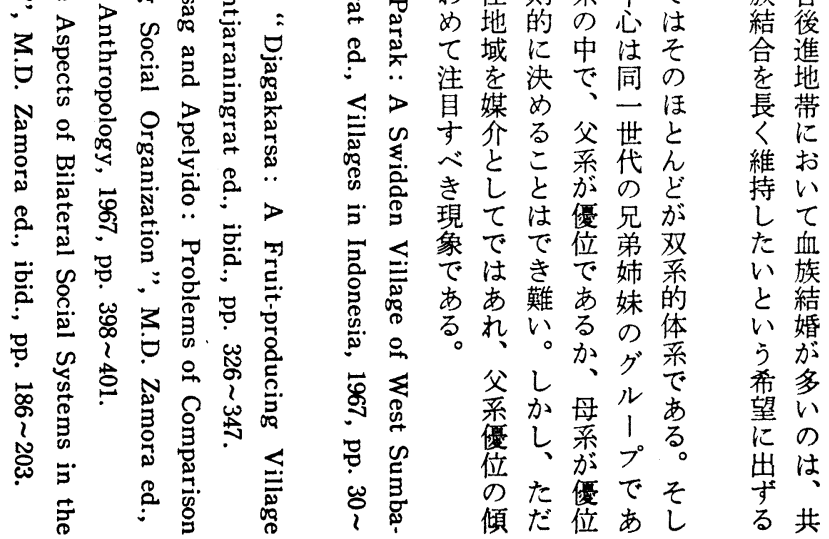


第 2 表 パンディトの世带の大きさ

\begin{tabular}{c|c|c|c|c|c|c|c|c|c|c|c|c|c|c|c|c}
\hline 一世濛当 & 1 & 2 & 3 & 4 & 5 & 6 & 7 & 8 & 9 & 10 & 11 & 12 & 13 & 14 & 18 & 合 計 \\
\hline 件 数 & 3 & 6 & 9 & 13 & 15 & 13 & 8 & 4 & 3 & 3 & 2 & 3 & 2 & 2 & 1 & 87 世帯 \\
\hline 合 計 & 3 & 12 & 27 & 52 & 75 & 78 & 56 & 32 & 27 & 30 & 22 & 36 & 26 & 28 & 18 & 522 人 \\
\hline
\end{tabular}

で的がるさまとるもでしなり り 世村い林た幅とと的

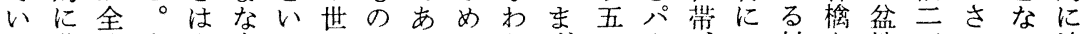

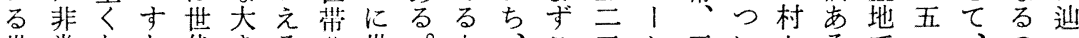

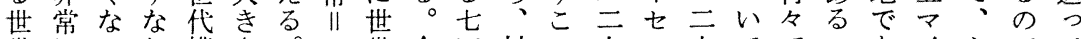
带にい構さ。千带全四村の人六てでいあイガて 複、ち成のも工員体世の村がト四みあはるルシあい

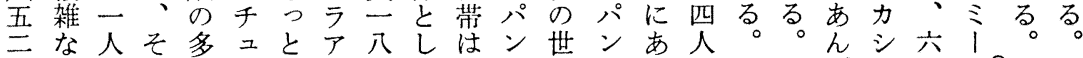

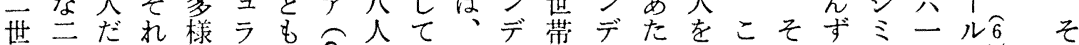

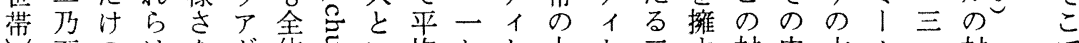

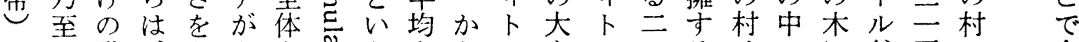
の至世市あを莺うをらのきだ二るはのに谷平名合 両世带最らる見しのと九六さあ二村一ウ囲の方は同 極带つもわ。れはがれ人九にる三で九卜ま問、、家

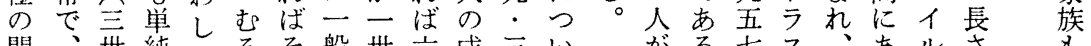

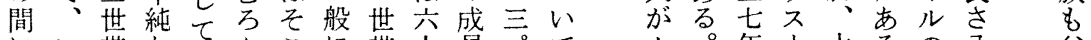
にい带ないんこに带人員䒔て公。年!水るの公父

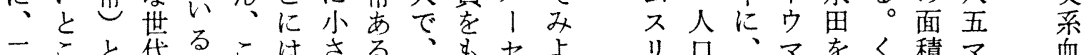

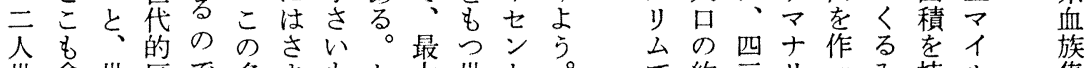

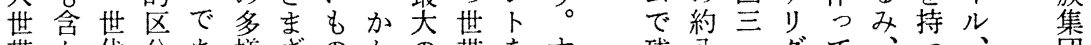
带ん代分あ㽷ざのかの㷼をす残分二グて、っ、団

第 3 表 カシミールの家族形態

\begin{tabular}{|c|c|c|c|c|c|c|}
\hline 世帶構成 & ホクル村 & コンムウ村 & コイル村 & クレリ村 & ベルナグ村 & \begin{tabular}{|l} 
ウトラスー \\
ウマナグリ村
\end{tabular} \\
\hline 核 家 族 & 12 & 8 & 11 & 6 & 6 & 26 \\
\hline 拡大家族 & 18 & 9 & 15 & 8 & 16 & 52 \\
\hline 合郭 & 30 & 17 & 26 & 14 & 22 & 78 \\
\hline
\end{tabular}

いいで合ての中

るるい只住パのと

ののるチんシ最こ

でで父ニでデ系ラる るる血アい卜位于 ○族のなのでュ そ彼○成い世あラ う等导員。带るア しは岂すはとは た他气、な通いパ 父の雪同わ常うン 亲世ஹじち村こデ 親带要村最落と1 族の芯落最染が卜 の中 世でを中多でき族 顖働もにく孤る体 がいっ住の立。亲 コてん場しこの
う自般七のれちウ家比族力 る 公 あのにた径二三十ぎがし態ミ打带世带

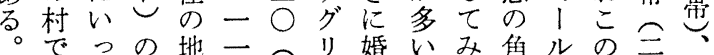
なてみ域っ三村姻のる度のウ六既 く村が内七○に形がとかパト世婚 て落、で四パお態注第らンラ率の もの村行パ、けに目等、デス等

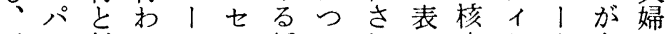
近ン村れ七ン婚い机の家卜ウ存と いデのわント姻てるご族のマ在そ 村 イ間ずトしのみ。とと世ナしの にトでかしは事る拉带グて子 嫁は行九は村例と夲にりい供 が彼わ例一落一ウ市家つ村るた せ等れつ五内五卜る族いを。ち

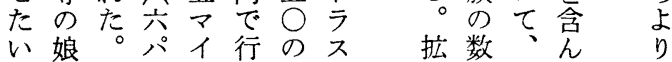
よを一、ルわう人学家だな 


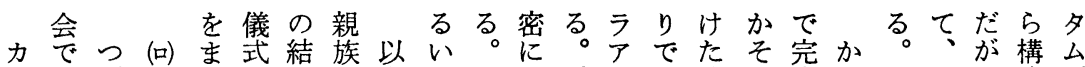

ンあぎつを束つ上はかな財はな後れ全があコ成ブ

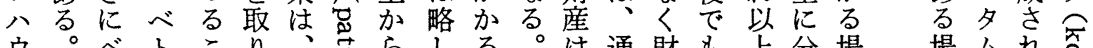

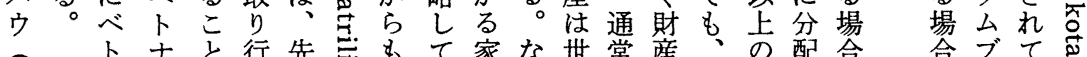

卜ナと行先吉もて家な世常産、の配合合ブて芯

栗ナム

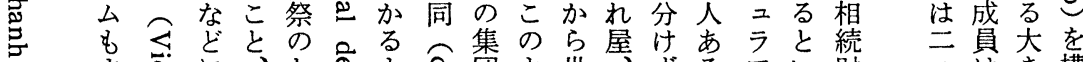

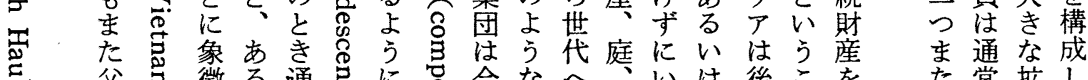

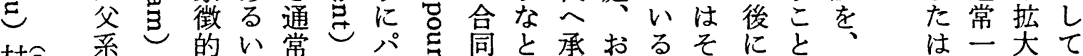

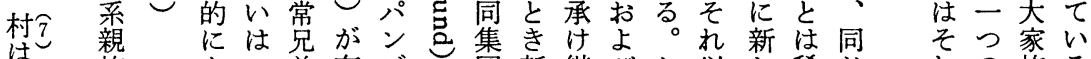

南族 あい弟存デし団新継びか以稀じ帒の族る。

㥣体 らと集在

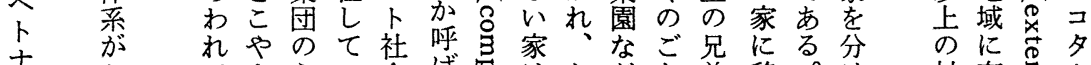

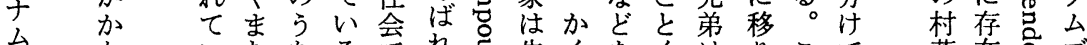

の ないたちるでれら先くをくはりこてて落在呑ブ

サ り る心最のはる。る祖て共同共住の住に方法

1 明

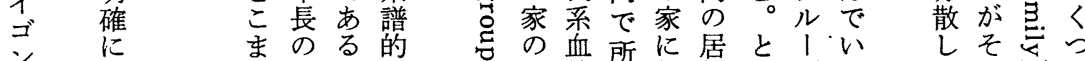

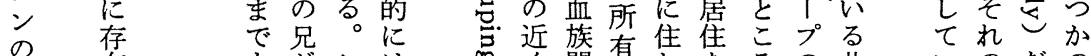

南在もがこは 恕簡有むをろの共いのだの

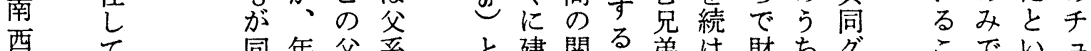

にて同年父系と建関る弟け財ちグこでいニ

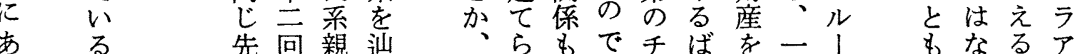

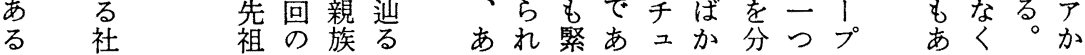

てっの一合は子民約る結には司わ成五四れ村

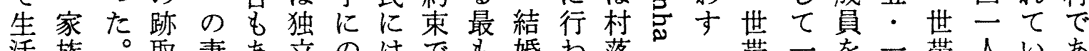
活族。取妻あ立のは岁婚わ落心马带一を一带人いあ 寸はりがる卞み村取重はれ民昰家が人含人員でるる る親 結。る父落り要家るがこ。独の方数あ。が

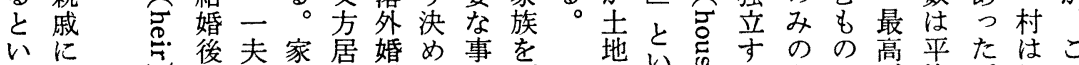

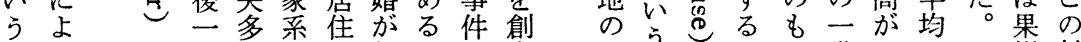

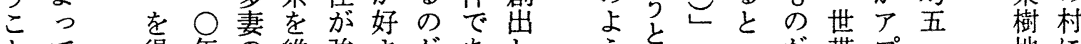

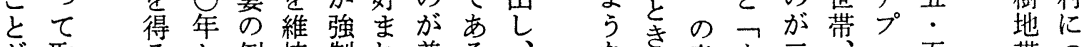
が取るか例持制れ普る、な意ナ三、五带つ

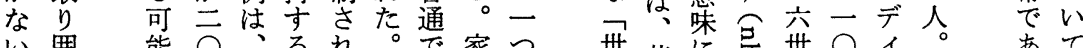
以囲能 ま性年三た居あ采の、帯右抢带人聚る。見

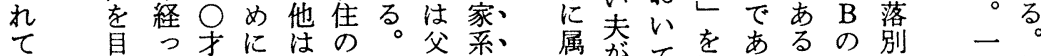

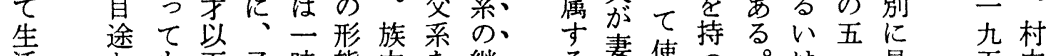
活々を市子時態内を継る妻使つ。は・見五内

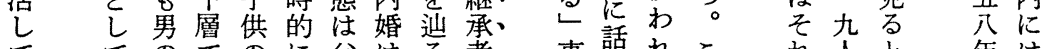
ててのでのに父はる者事話れこれ人と年は 第子はな父方夕多物㤂る机以で最に六 る三をない方のブ結な忧は低世つ

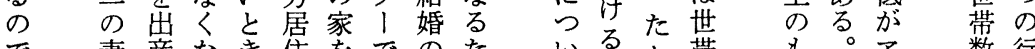
で妻産なき住をでのたいると带をる。ア 数行

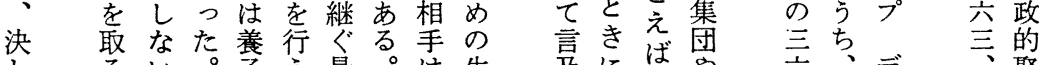

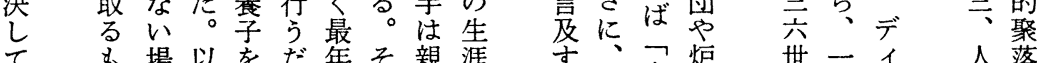

て も場以をだ年そ親涯尔、炉世一个人落

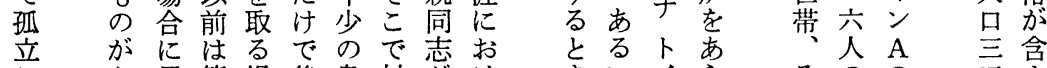

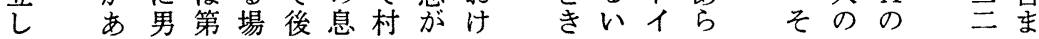


第 4 表 世带と人口数

\begin{tabular}{c|r|r|r|r}
\hline & 1957 & 1964 & 1965 & 1966 \\
\hline 全 人 口 数 & 559 & 652 & 660 & 689 \\
\hline 世 帯 数 & 75 & 100 & 103 & 108 \\
\hline 平均世带員数 & 7.5 & 6.5 & 6.4 & 6.4 \\
\hline
\end{tabular}

持式つ族族数しる祭で

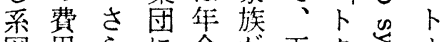

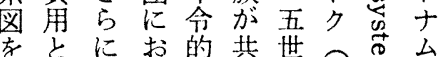
守家讨熥代呑急に 先産る階の前斿で 衫祖道梯先のしでけ ば祭し德ゔ祖先す弯る なのて上け筯なる。親

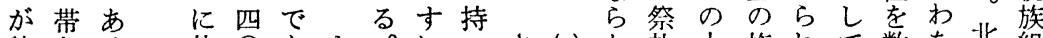

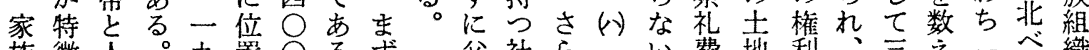

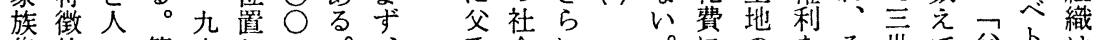
集的口第六しフ。、系会にコ。にのをそ世て父卜は

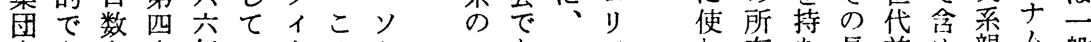

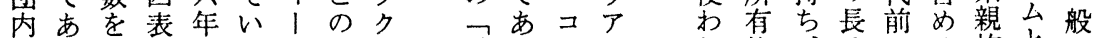

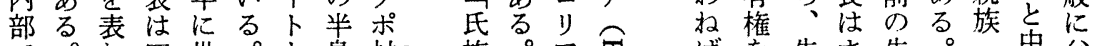

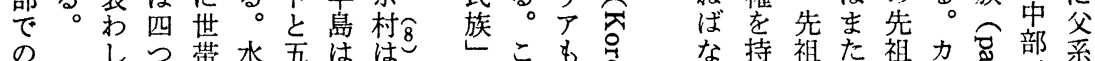

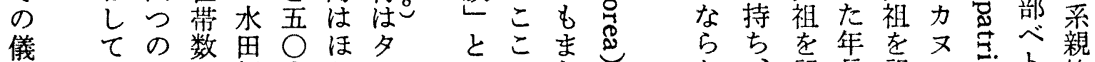

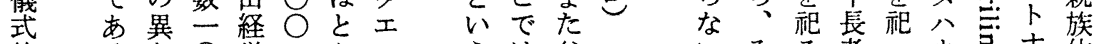

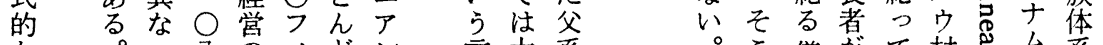

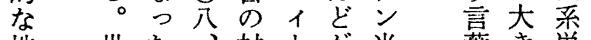
地世た、村 | が半葉き単 位带年人でト山島的な采 員次口あのでの使親の

財数に六る間あ中角族親

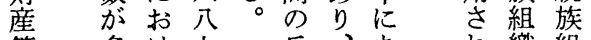

管多尔兵索热織組 お方世で上は村い指を こ儀がて村品台采 彼か武ないの仓に はらるる場打㤩

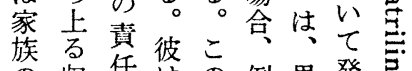
收任社例男発寻 墓入を父外亲見 をはもの系的をさ 維儀持親親に通れ?

伝 1 事 ら成的のるのその合社で哥族立威によ

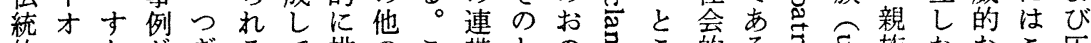

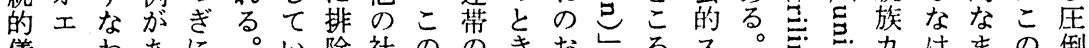

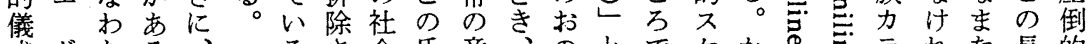
式ドちるるるさ会氏意、のとでケか怘テれた 長的

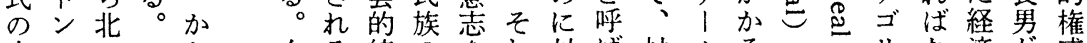

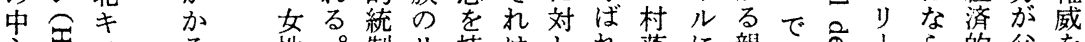

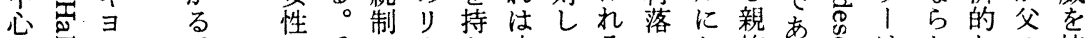

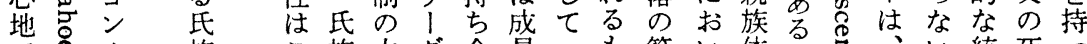

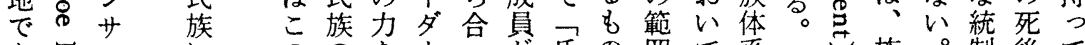

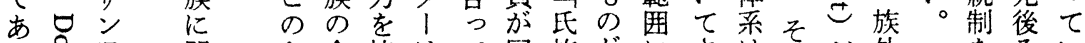

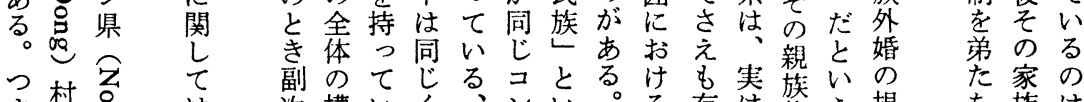

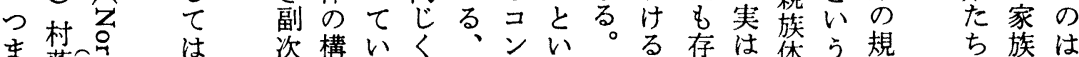

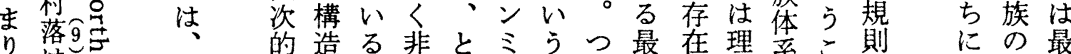
り注的造る。非とミうっ最在理系こ則にの最

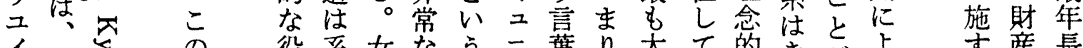

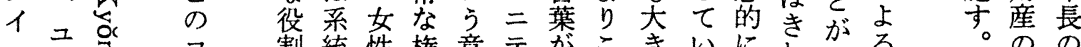

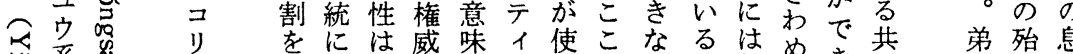

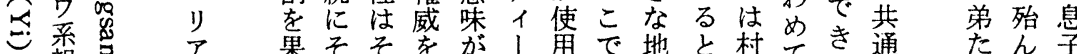

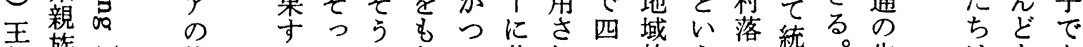
朝族他とてしちょ共れつ的えの統。片はをあ

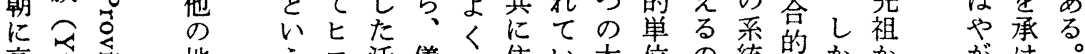
高を吉地 うエ活儀こ住い大位の統的かか加がけ

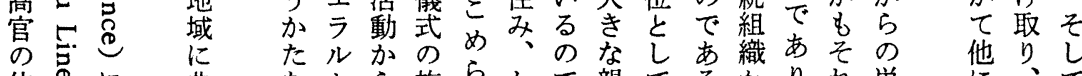

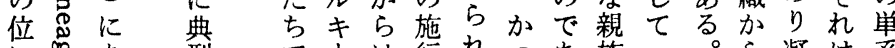
に型等市は行れつあ族つ。凝は采 的加を絶相る集氏 国集父的 いの公な構対そい互。団族民的系親 他 り ᄂ 出ま理 てた想 独権的 
に細氏同系つ独いうの範带て

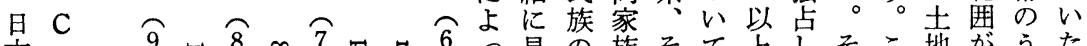

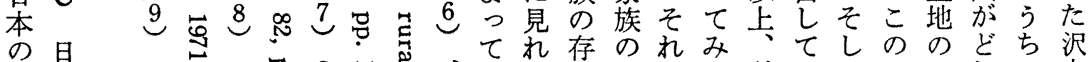

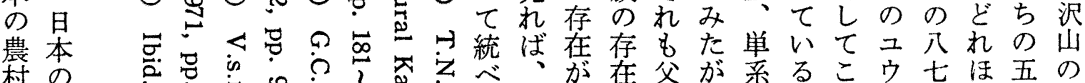

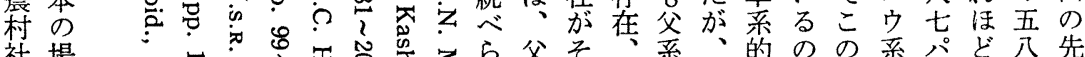

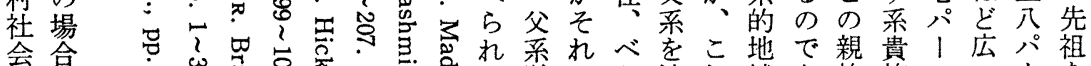

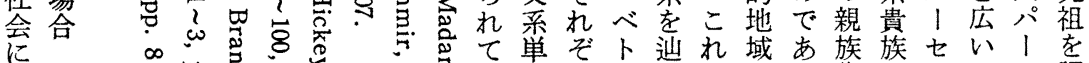

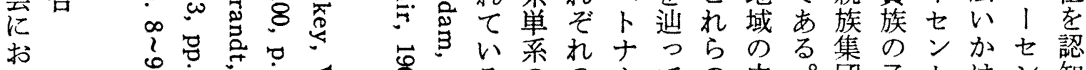
い小宓るのの㕕ての中。団子卜はン知

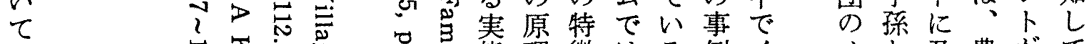

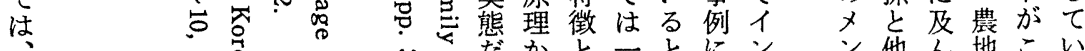

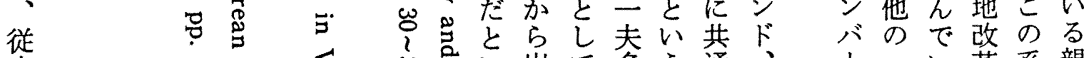

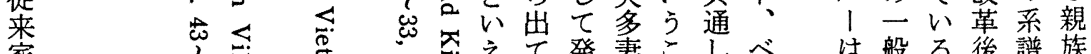
家 l

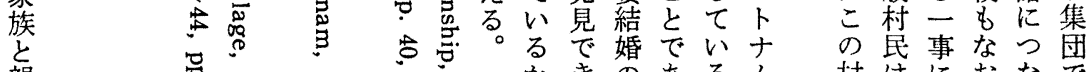

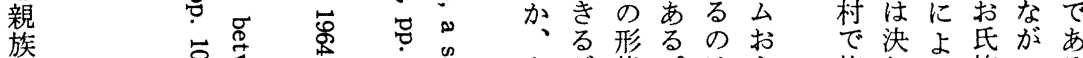

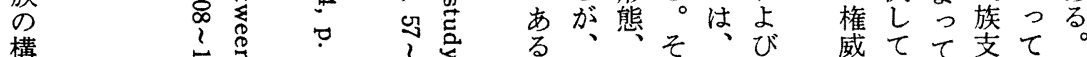

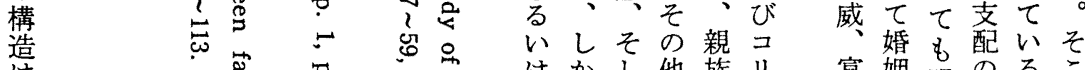
父

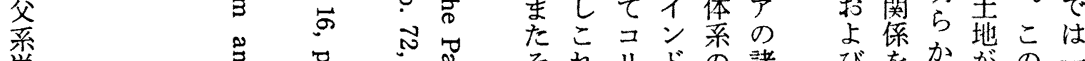
単 系

よ

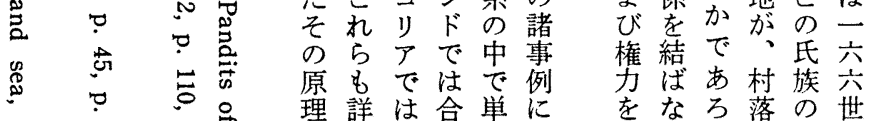

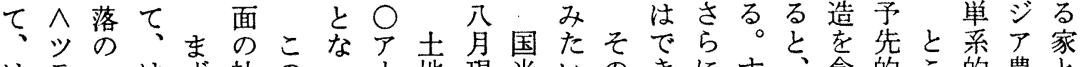
はラ—はす社のう〉地現光いのきにす、念的こ的農と じ $\vee$ 定じ第会村てル所在村。事な $\mathrm{A}$ ない頭なろ地村同 め組のめ- 的落い層有、落例くのわさに原で域に族 て織共てに性のる一加法なな双ちさお理従のつの $\wedge$ 同イ、格社。六ら数、しる系現かきを来中い構 个中組エそ考方み四石て。的在右な傍まにて造 エに織とれ得的、た二川地日とがらで包のを 、二をなはて核三農戸県ぎ域本はらにの搨系特 と定基るへはは しの礎こッじ ^ |階う至、性村な現い本れ的と て地にとラめイ五磻ち郡能格のっ在て農る原す 認位しが、てエ ○は農柳登㤎家たの、符こ理る めをたで制イ、ア家田平加族側日別のとに ら占制き度エで れめ制る视が農ア族なるさ

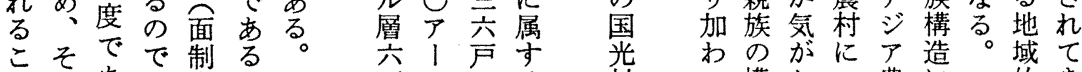
とれああ度ここ六ルでる村っ構かつ農に的き がにるる文のあ村落て造りい村関類た

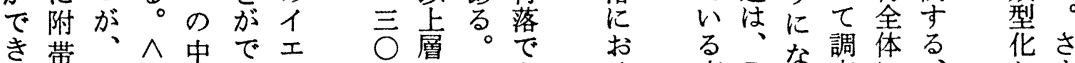

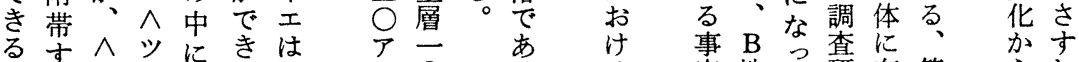
のするイラ組るつき

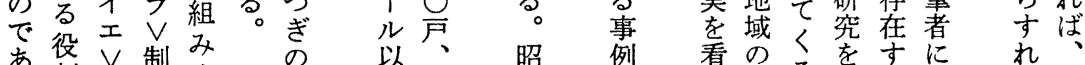

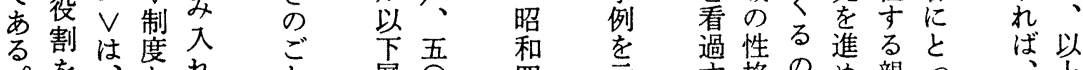

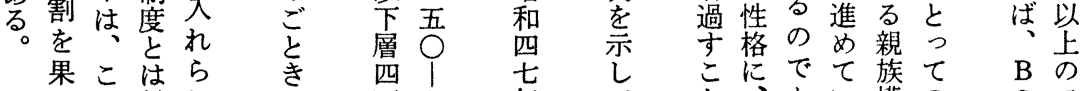

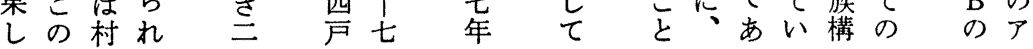


あ落へなぬッるそ核おおとなそ譲てたはこす構

るのツのにサ。しはさいしかれ、或場とる成すへ

寄ラではン村て^てててのはッ渡そ合村もも户なッ り $、$ あ、落母才、、の二一ラ尔のは落、のはわラ 合のる是親芮親ヤこへ地戸個 $\vee$ の後、減と共ち $、$ い共。非親では、のコ位ののはで、会寄らお有、制 や同 $\wedge$ と新はそで村、孝い独市新議りすを地 (1) 度

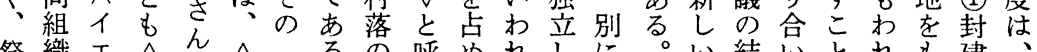

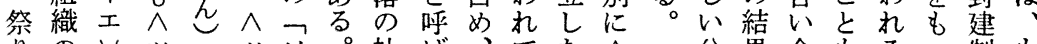

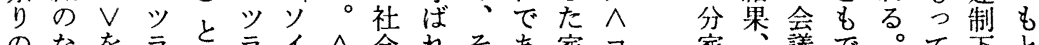

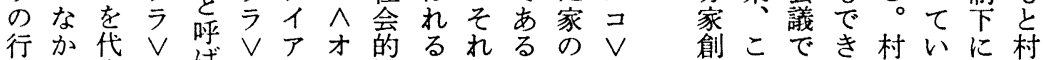

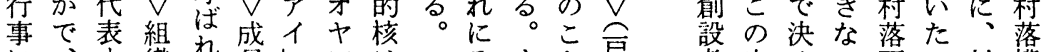

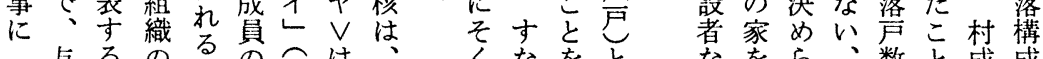

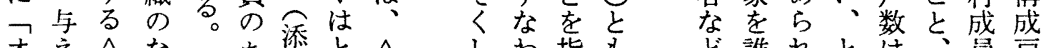

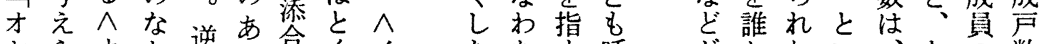

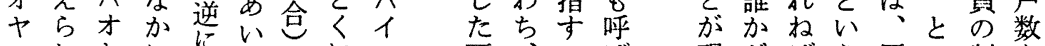
ツれヤに界だと声、のば現がばう原い制を

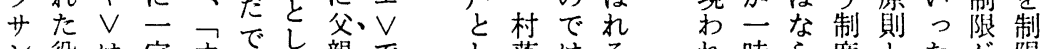
ン役は定才でし親でし落はる持ら度とたが限

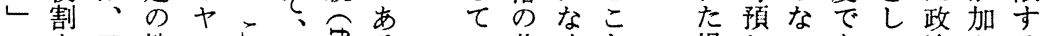

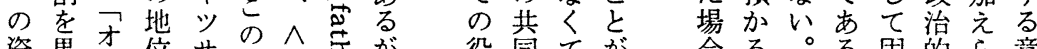

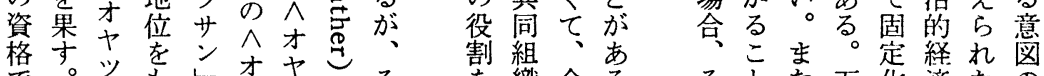

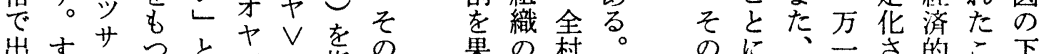

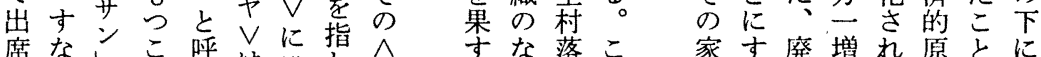

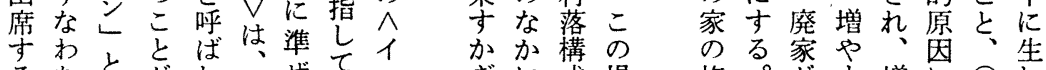

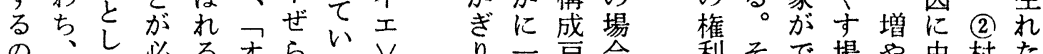

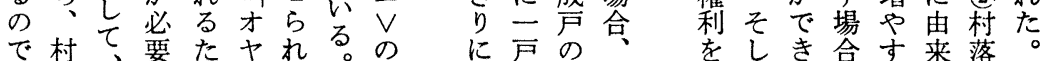

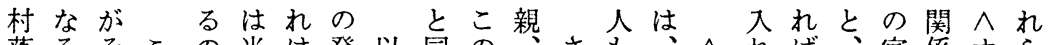
落るそこの当は発以同の程さも、^れば、家係オら第 のとのので然血達上様場烏らあへイら、そのをヤれ而

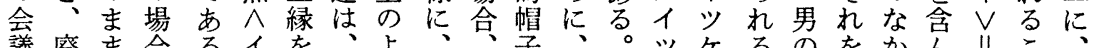

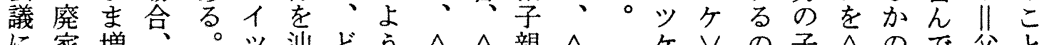

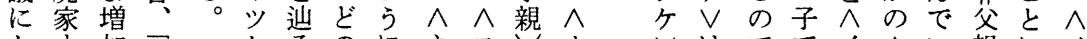

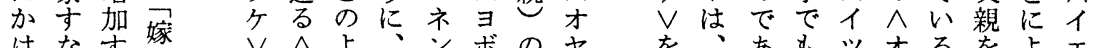

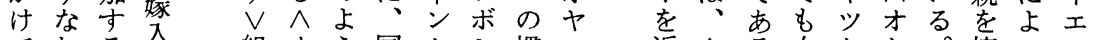
てわる。組オう国キジ慣・近へる女ケヤ。擁っ、

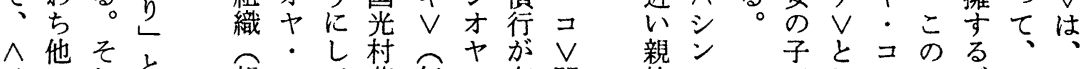

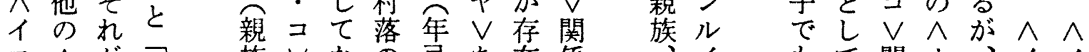

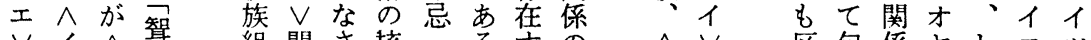

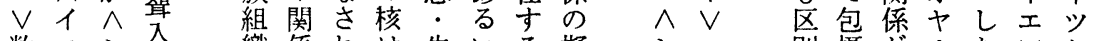
数エシ入織倸れは先いる擬 シへ別揣がさた

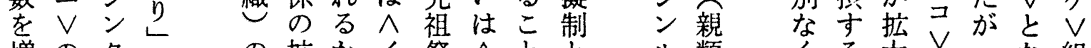
増の名の の拡かイ祭 $\wedge$ と六類くる。関っな組

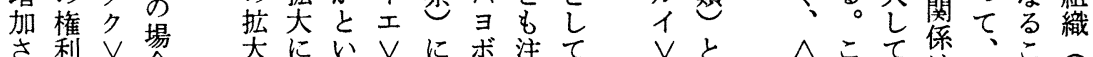

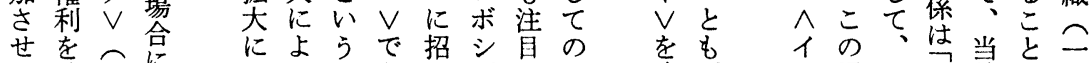

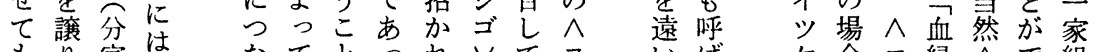

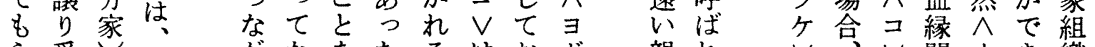
ら受孞なをたるはおおボ親机、只、関才き織

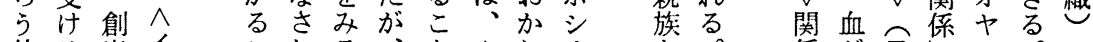

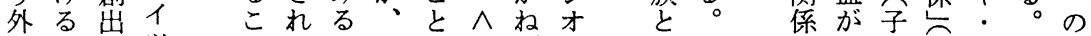

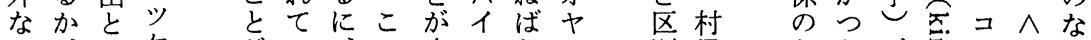

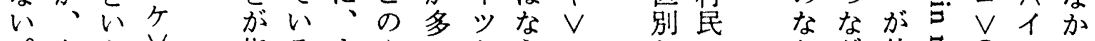

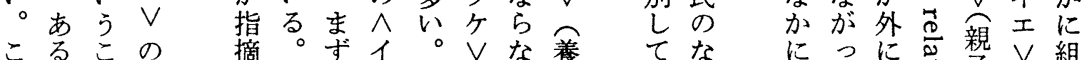
こるこの成摘こずこ

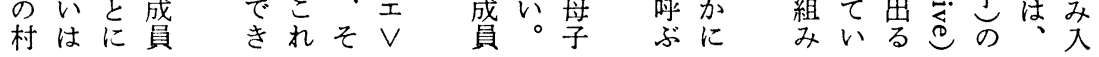




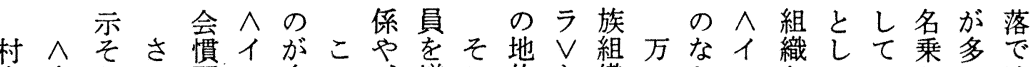

内事うて習ツ多の、增こ位を織一かッをてのりいは

1 例。つとケい村擬やでと持は、でケしは役へ。共

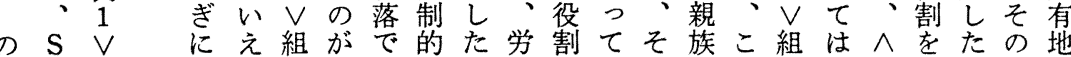

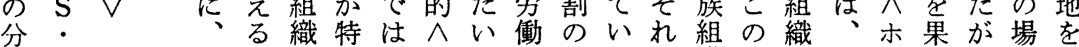

家 $\mathrm{R} S \mathrm{~S} こ の の$ 徵、オ場組上なな織よ共ンさつ合持

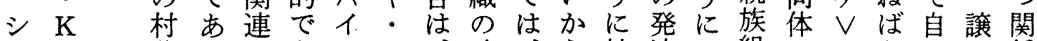

ン家落ろのあトコ、確ら、搪達し組のへな㫕り係

タのにうメるコ、ヘ保両、大がて織中本らは受も

ク親お。力。

○族 けこ結係ラ親にしる村限の他登他姓たっ

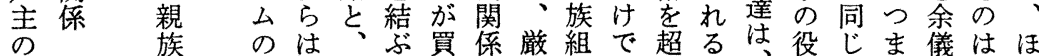

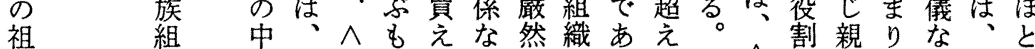

父織似泀のなどたのるて

のにら上ボがいのる成が他兴果組のさりど

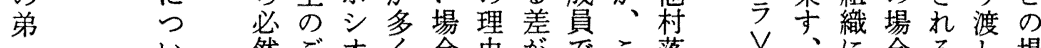

- $\quad$ 然ごオく合由がでこ落䜤々、に合るし 場

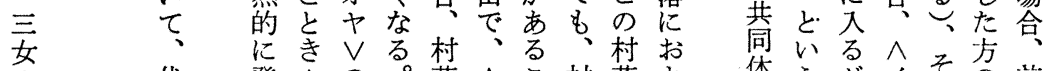

の 代発 $\wedge$ の。落 $\wedge$ こ村落よ

嫁表生 $ッ$ 関芮イと落のん

ぎ的告ラ係皆に共中た

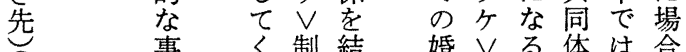

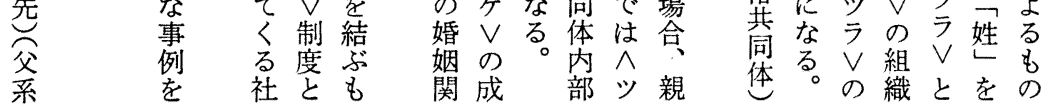

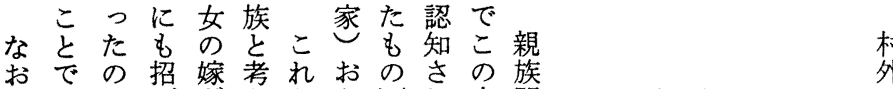

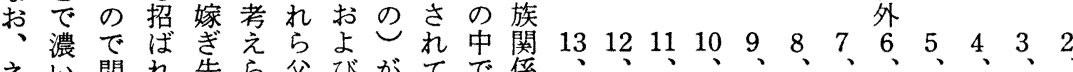

ネ関れ先篗て父びがて

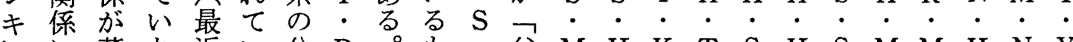

に 薄な近

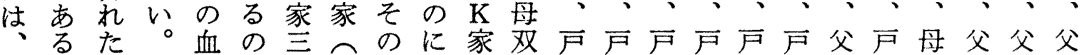

こかのす縁は戸古他はの系主主主主主主の主方のの方

のらでな関、のい右、シレののののののイののイイの

外であわ係 $\mathrm{S}$ 分に $\mathrm{S}$ ンに三三長四三長卜妻イトトイ

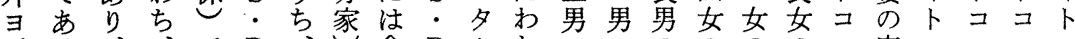

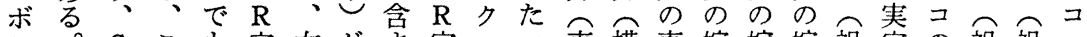

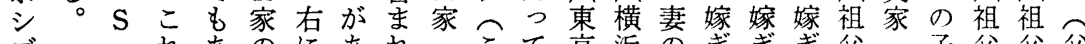

ヨ゙・れあのにあれてこて京浜のぎぎぎ父交父父

の $\mathrm{R}$ らるみ見りて 1 のい先実先先の のののの

A. 家三。でた、いし場る 家る弟市妹妹妹

- は豆他あよ都な气合こ

S 最は、るるう合い゙主父と

家近、三こに严が主系が

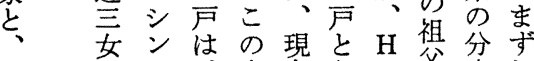

A 加夕家在な. 分家わ

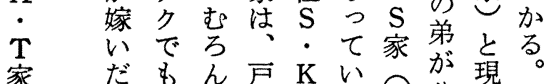

招 以年ネ主家る古分在々

照う経キ三親分しもる

の主ののの

息息息息

子 母息息

分寞公公父 


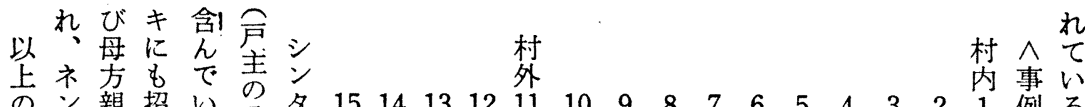

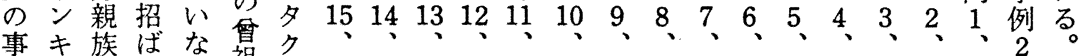

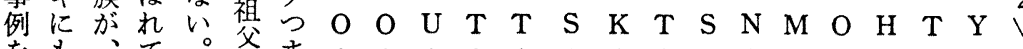

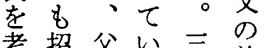
考招爷心严弟

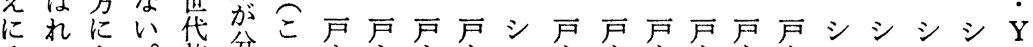
入てよ。前軞の主主主主ン主主主主主ンンンン家

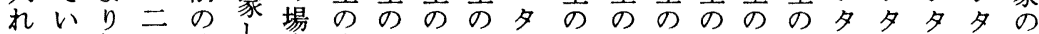
なる優世分た合先妹姉妻ク母娘長祖祖祖クククク親 が。位代家を父妻ののの气のの男母母母乞乞乞乞族

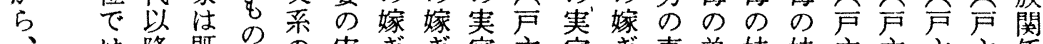
こ は降既さ㐫䒠ぎぎ先主家ぎ妻弟妹妹主主主主係 のるは含を分公公祖実孫嫁嫁祖父父弟

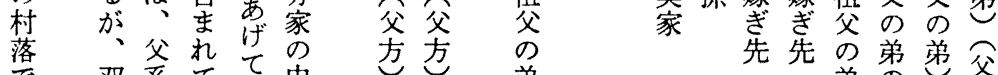
落双系て年弟

は、方のいるに

ぎ親家いがは

ぎ族公

ご 中方交族巨

き親る。中

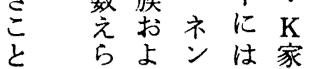

父
系
分
家

弟兄齐 子公系 紊公采分

の系分

分永家

家分

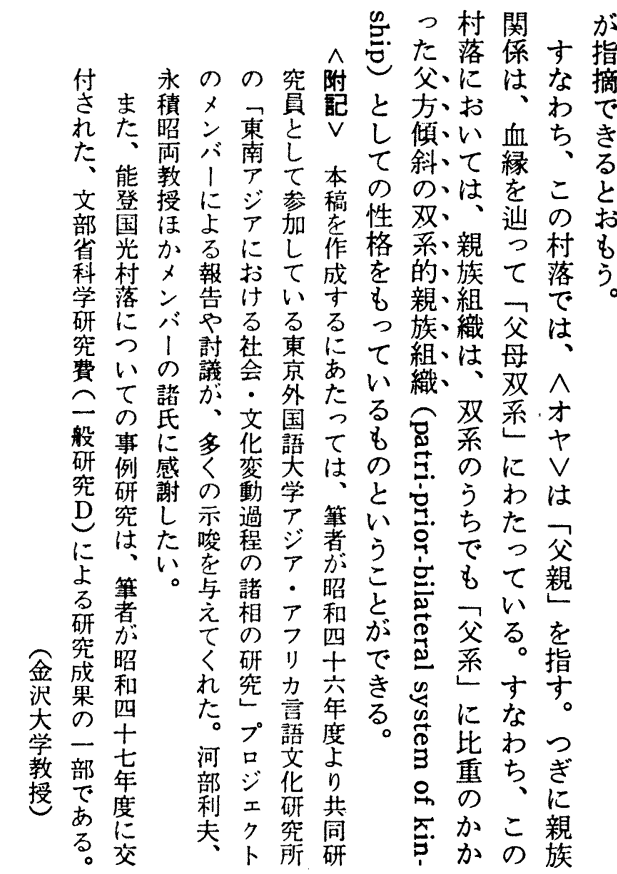


when it exists in both tsura institution, a kind of village community, and $i k k e$ organization, a kind of kinship system. The nucleus of this ie is oya (parents), in this case especially the father (the mother follows the father). From the oya, with the father as the nucleus, the oya-ko relationships (the parents-children relationships) extend in the direction of both patrilineage and matrilineage. Thus I can define the kinship organization in this village as a parti-prior-bilateral system of kinship. 
the individual characteristics of the Japanese rural social structure, for instance $i e$ (the Japanese family) and dozzoku (the Japanese extended family system) and so on. However, such a method might loses sight of homogeneity which exists among Asian countries even though it emphasizes heterogeneity.

In this paper, I would like to take a point of view of seeking identity rather than variety, and homogeneity rather than heterogeneity. It is my viewpoint in this paper that the understanding of the Japanese rural society must come after understanding the other Asian countries.

I have adopted the principle of lineage of the family and kinship system which are thought to be the fundamental structure of the Asian rural societies as the criterion for finding identity between the societies. Then we can devide Asian rural societies into two areas A, an Area of Bilateral System, and B, an Area of Unilineal.System. Most countries in the south west islands belong to the A-Area, and the countries in the north east continent belong to B-Area. While Indonesia, Philippines and Malaysia and so on would be included in the former area, India, Thailand, Vietnam, Pakistan, China and Korea and so on are the latter. This paper seeks to identity which area Japan belongs to.

The case studies are as follows.

A-Area: Some villages in Indonesia and Philippines have been considered as the case studies. In this area, the family type is that of nuclear family. It cannot be determined whether male or female lineage system are dominant. The way of living might indicate the superiority of the male (patrilocal). Marriages between cousins are more frequent. The kinship structure is the bilateral system. The nuclear group of the kinship system is the sibling group. We cannot decide whether the patrilineage or matrilineage is dominant. But in the modernized areas, patrilineage may be dominant.

B-Area: Some cases in India, Vietnam and Korea have been considered. The family type compared with A-Area has the characteristics of the extended family system. We will give attention to the compound family in India, the polygamy in Vietnam, and the clan in Korea. The kinship system is the unilineal system.

C-Area: The case of Japan. The established theory which has been dominant concerning family and kinship was that ie and dozoku were in the parti. unilineal system. If it were true, Japan should be included in B-Area. However, when we study the Japanese rural society compared with other Asian societies we could find in Japan the factors of both $A$ and $B$ areas.

For testing this hypothesis, I have studied Kunimitsu village in Noto Peninsula, Ishikawa Prefecture.

The social nucleus of this village is the $i e$. Ie can be recognized as ie 


\title{
The State of the Studies on Asia
}

\author{
Hiroichi Yamaguchi \\ Institute for Developing Economies
}

In this article the author makes some critical appraisals of the studies on Asia achieved by Japanese scholars, and tries to make some suggestions for the theory of Asian society.

In the process of modernization Japan had unique relations toward Asian countries. Modern Japan approached to the Western world by the sacrifice of of Asia, especially by Korea and China. After World War II has the situation changed drastically? We cannot but denying it. Japan and China had not been in contact, but Japan's economic aid was given mainly to the Southeast Asia, and now Japan's economic conquest is a most serious problem there.

Japanese scholars have payed attentions to Asia against these situations Studies on China and Korea were faciliated by Japan's national policies. Many

researches were made, but we have not a systematic one. For the theory of Asian society we must make good use of these achievements.

As for India, Japan had little interest in her and a few studies have made. We are handicapned in religions, languages, and the scarcity of data. Moreover, we have little knowledge about England who had ruded India for a long time. But Japanese scholars specialized in India have two merits. They can make use of the results obtained in studies on China and Korea, and the histories of Japan, Germany and Russia give some lessons for India. Some day a whole, systematic study on India will be perfected.

\section{The Structure and Principle of the Family and Kinship System in Asian Rural Societies}

\author{
Tetsuo Ninomiya \\ Kanazawa University
}

Having the belief that we could find varieties of principle and structure in Asian rural societies, the Japanese rural sociologists have been analyzing only Japan. Through these tasks, some sociologists have been able to find 